\title{
Duration of Care Trajectories in Persons With Dementia Differs According to Demographic and Clinical Characteristics
}

Citation for published version (APA):

Janssen, O., Vos, S. J. B., Handels, R., Vermunt, L., Verheij, R., Verhey, F. R. J., van Hout, H., Visser, P. J., \& Joling, K. J. (2020). Duration of Care Trajectories in Persons With Dementia Differs According to Demographic and Clinical Characteristics. Journal of the American Medical Directors Association, 21(8), 1102-1107.e6. https://doi.org/10.1016/j.jamda.2020.01.008

Document status and date:

Published: 01/08/2020

DOI:

10.1016/j.jamda.2020.01.008

Document Version:

Publisher's PDF, also known as Version of record

Document license:

Taverne

Please check the document version of this publication:

- A submitted manuscript is the version of the article upon submission and before peer-review. There can be important differences between the submitted version and the official published version of record.

People interested in the research are advised to contact the author for the final version of the publication, or visit the DOI to the publisher's website.

- The final author version and the galley proof are versions of the publication after peer review.

- The final published version features the final layout of the paper including the volume, issue and page numbers.

Link to publication

\footnotetext{
General rights rights.

- You may freely distribute the URL identifying the publication in the public portal. please follow below link for the End User Agreement:

www.umlib.nl/taverne-license

Take down policy

If you believe that this document breaches copyright please contact us at:

repository@maastrichtuniversity.nl

providing details and we will investigate your claim.
}

Copyright and moral rights for the publications made accessible in the public portal are retained by the authors and/or other copyright owners and it is a condition of accessing publications that users recognise and abide by the legal requirements associated with these

- Users may download and print one copy of any publication from the public portal for the purpose of private study or research.

- You may not further distribute the material or use it for any profit-making activity or commercial gain

If the publication is distributed under the terms of Article $25 \mathrm{fa}$ of the Dutch Copyright Act, indicated by the "Taverne" license above, 
Original Study

\title{
Duration of Care Trajectories in Persons With Dementia Differs According to Demographic and Clinical Characteristics
}

\author{
Olin Janssen $\mathrm{MSc}^{\mathrm{a}, *}$, Stephanie J.B. Vos PhD ${ }^{\mathrm{a}}$, Ron Handels $\mathrm{PhD}^{\mathrm{a}, \mathrm{b}}$, Lisa Vermunt MSc ${ }^{\mathrm{c}}$, \\ Robert Verheij PhD ${ }^{\mathrm{d}}$, Frans R.J. Verhey MD, PhD ${ }^{\mathrm{a}}$, Hein van Hout MD, PhD ${ }^{\mathrm{e}}$, \\ Pieter Jelle Visser MD, PhD ${ }^{\mathrm{a}, \mathrm{b}, \mathrm{c}}$, Karlijn J. Joling $\mathrm{PhD}^{\mathrm{e}}$
}

a Alzheimer Center Limburg, Department of Psychiatry and Neuropsychology, School for Mental Health and Neuroscience, Maastricht University, Maastricht, the Netherlands

${ }^{\mathrm{b}}$ Department of Neurobiology, Care sciences and Society, Karolinska Institutet, Stockholm, Sweden

${ }^{\mathrm{c}}$ Alzheimer Center Amsterdam, Department of Neurology, Amsterdam Neuroscience, Vrije Universiteit Amsterdam, Amsterdam UMC, Amsterdam, the Netherlands

${ }^{\mathrm{d}}$ Nivel, Netherlands Institute for Health Services Research, Utrecht, the Netherlands

e Amsterdam UMC, Vrije Universiteit Amsterdam, Department of General Practice and Elderly Care Medicine, Amsterdam Public Health Research

Institute, Amsterdam, the Netherlands

\section{A B S T R A C T}

Keywords:

Dementia

home care

institutional care
Objectives: To estimate (1) the duration of no formal care, home care, and institutional care after dementia diagnosis, and (2) the effect of age, sex, living situation, dementia medication, migration background, and income on this dementia care duration.
This work was supported by the Netherlands Organisation for Health Research and Development (ZonMw) under grant agreement No. 733050403; and the Innovative Medicines Initiative 2 Joint Undertaking under grant agreement No. 116020.

Data were collected within the 'Identifying BESt practices In DEmentia care' (BESIDE) study, which aimed to identify and characterize best practices in care trajectories of community-dwelling persons with dementia and their family caregivers. The present study was conducted in collaboration with the Real-World Outcomes across the Alzheimer's disease spectrum for better care: Multi-modal data Access Platform (ROADMAP) project, which aimed to identify and use relevant outcomes and data sources across the Alzheimer's disease spectrum to create a disease progression model (38).

All authors have completed the ICMJE uniform disclosure form at www.icmje. org/coi_disclosure.pdf and declare: no financial relationships with any organizations that might have an interest in the submitted work in the previous 3 years; no other relationships or activities that could appear to have influenced the submitted work. OJ received through her institution research support from Biogen and the Innovative Medicines Initiatives. SV received research support from ZonMw, Alzheimer Nederland, and the Innovative Medicines Initiatives during the conduct of this study. RH reports the following outside this study: consulting fees from Piramal, Roche and Eisai; grants from Horizon 2020, JPND Joint Programing Neurodegenerative Disease Research, IMI Innovative Medicines Initiative, and national, European and patient charity funding organizations and private-public collaborations (ZonMw Netherlands; Alzheimer Netherlands; Dutch Flutemetamol Study; Alzheimer Research UK; Swedish National study on Aging and Care; European Brain Council). LV received through her institution research support from Alzheimer Nederland, European Brain Council, and the Innovative Medicines Intiatives. PV reports grants from Innovative Medicine Initiatives and grants from ZonMw during the conduct of the study, nonfinancial support from GE Healthcare, and grants from Biogen, outside the submitted work.

The lead author affirms that the manuscript is an honest, accurate, and transparent account of the study being reported; that no important aspects of the study have been omitted; and that any discrepancies from the study as planned (and, if relevant, registered) have been explained.
The ethics committee of the VU University Medical Center confirmed that the Medical Research Involving Human Subjects Act (WMO) does not apply to the BESIDE study, therefore official approval was not required. Data provided by NIVEL were pseudonymized at each general practice site, and patients were informed about the use of their pseudonymised record data and given the opportunity to object. Data provided by Statistics Netherlands was anonymized. Since these data were recorded for routine administrative purposes no informed consent of the persons included in this database was obtained. The Personal Data Protection Act and the Act on Statistics Netherlands allow for the use of registry data for scientific purposes. This study has been approved according to the governance code of Nivel Primary Care Database, under number NZR-00315.063.

The BESIDE study has obtained funding from the Netherlands Organisation for Health Research and Development (ZonMw) under grant agreement No. 733050403 ("Identifying best practices in care trajectories of community-dwelling persons with dementia. A comparison of care trajectories, quality indicators and costs extracted from routine care registrations and health insurance data"). The ROADMAP project has received funding from the Innovative Medicines Initiative 2 Joint Undertaking under grant agreement No. 116020 ("ROADMAP”). This Joint Undertaking receives support from the European Union's Horizon 2020 research and innovation programme and EFPIA. It is also supported by the Medical Research Council Dementias Platform UK (MR/L023784/1 and MR/009076/1). The researchers confirm independence from funding sources and all authors had full access to all of the data in the study and can take responsibility for the integrity of the data and the accuracy of the data analysis.

Access to the data sources used in this study can be applied for through the Nivel Primary Care Database and Statistics Netherlands governance bodies.

* Address correspondence to Olin Janssen, MSc, Alzheimer Center Limburg, Department of Psychiatry and Neuropsychology, School for Mental Health and Neuroscience, Maastricht University, PO Box 616, 6200 MD Maastricht, the Netherlands.

E-mail address: olin.janssen@maastrichtuniversity.nl (O. Janssen). 
Design: Longitudinal retrospective study using routinely recorded general practice electronic health records linked with population-based healthcare and mortality data.

Setting and participants: In total, 11,012 community-dwelling persons who received an incident dementia diagnosis and were listed in a Dutch general practitioner database from 448 general practices in the Netherlands.

Methods: Using multistate modeling analyses, we estimated the mean duration of care types (no/home/ institutional care) for different ages based on simulations of transition rates and examined the influence of demographic and clinical factors on these durations.

Results: From dementia diagnosis onward in 85-year-old men, the mean duration without formal care was 0.7 years, of home care 1.7, and institutional care 1.1 years. In 85 -year-old women, the duration without formal care was 0.8 years, of home care 2.3 , and institutional care 2.3 years. Total care duration was 3.5 years in 85-year-old men and 5.4 years in 85-year-old women. In men, the duration of home care was longer compared with no formal care and institutional care. The duration of no formal care was longer in persons not living alone, without prescribed dementia medication, with a non-Western migration background, or with a higher income. The duration of home or institutional care was longer in women, persons without polypharmacy, in those living alone, or those with a Western background. Conclusions and implications: Our findings help to increase understanding of long-term dementia care trajectories and show that demographic and clinical factors determine the duration of care types. Our results can contribute to the organization of healthcare resource planning and monitoring of the effects of healthcare policy and interventions.

(c) 2020 AMDA - The Society for Post-Acute and Long-Term Care Medicine.

Dementia is a long-duration disease and provides a major burden to the patient, caregiver, and healthcare system. The dependency on care and care type needed changes with disease progression. ${ }^{1}$ To aid healthcare resource planning, it is necessary to understand care duration and factors that determine care use such as demographic and health-related factors and migration background.

Formal dementia care consists of home care and institutional care. Previous studies on dementia care duration focused on duration from diagnosis to institutionalization ${ }^{2}$ and from diagnosis to death but did not distinguish between home and institutional care duration. ${ }^{3}$ Furthermore, there is limited information on the duration after diagnosis without home or institutional care. Previous studies on care use also had small sample sizes, ${ }^{4,5}$ included memory clinic-based samples that are less representative of the general population, ${ }^{6,7}$ did not link dementia duration to formal care resource data, ${ }^{4,8}$ or had a short follow-up time. ${ }^{6}$

Moreover, little is known about factors affecting care-type duration. One study showed that older age and male sex were associated with shorter time of home care, ${ }^{6}$ and living alone was associated with a greater institutionalization risk in men compared with women. ${ }^{9}$ Dementia medication use postponed time to institutionalization ${ }^{9}$ but did not influence institutional care duration. ${ }^{10}$ Lower concomitant medication use was associated with longer dementia duration. ${ }^{11}$ Previous studies indicated that minority ethnic groups tend to access care services later in the disease, ${ }^{12}$ and cultural differences in informal caregiving likely influence formal care use. ${ }^{13}$

We aimed to investigate the duration of different formal care types defined as no formal care, home care, and institutional care in persons with a dementia diagnosis recorded in routine general practitioner (GP) electronic health records (EHRs) in the Netherlands. We examined age, sex, living situation, polypharmacy, dementia medication, migration background, and income effects on care transitions and duration.

\section{Methods}

\section{Data Sources}

\section{Patient selection}

The Netherlands Institute for Health Services Research Primary Care Database (NIVEL-PCD) includes routinely recorded care data, pseudonymized at source, from 1.7 million patients from a sample representative of Dutch general practices (10\%). ${ }^{14}$ Every person living in the Netherlands is registered at a general practice, and GPs act as gatekeepers to specialized care. Diagnoses assessed by medical specialists are copied into the GP EHR system, using the International Classification of Primary Care (version 1). ${ }^{15}$ We included 11,012 community-dwelling persons born before 1965 with an incident International Classification of Primary Care diagnosis code P70 (dementia diagnosis) in the NIVEL-PCD from 2008 to 2014. We excluded patients with Down syndrome and patients who could not be linked to the administrative data sources ( $n=1766$, see below).

\section{Administrative data sources}

Information on demographics, formal care, medication prescriptions, and death was derived from administrative data sources at Statistics Netherlands. ${ }^{16}$ Demographics and death dates were taken from the Dutch population registry. Living situation was extracted from the system of social-statistical household composition registry. Medication use was extracted from the GP EHR and National Healthcare Institute database at Statistics Netherlands. Net annual household income corrected for household size, and composition was derived from the administrative household income registry (available for $\mathrm{N}=10,979$ ). Health resource utilization statistics were taken from insurance data from the Dutch Central Administration Office database. Care use registrations were followed up from diagnosis until the end of 2014.

\section{Dementia Care States}

We developed a model containing 3 care states and death as end stage: (1) no formal care, (2) home care, and (3) institutional care (Supplementary Figure 1). No formal care was defined as not receiving any registered form of care except regular GP care. Home care was defined as domestic assistance, personal care for activities of daily living, home nursing support (including palliative care received at home), day care (included since 2011), or any combination thereof for at least 30 days. Institutional care was defined as receiving residential care in a nursing home, residential home, or psychiatric home, including palliative care received within an institution, for at least 30 days. 


\section{Demographic and Clinical Predictors}

Predictors included baseline age, sex, living situation, polypharmacy, dementia medication, migration background, and socioeconomic status. Living situation was defined as living alone or living together with another person. Dementia medication ATC4 code N06D prescriptions were included. Polypharmacy was defined as 5 or more medication group prescriptions. ${ }^{17}$ Migration background was divided in a non-Western migration background group (Surinamese, Antillean, Aruban, Moroccan, Turkish, or other non-Western migration background) and a Western background group (all other persons). For socioeconomic status, we used a median split to dichotomize income as more or less than $€ 19,069$.

\section{Statistical Analyses}

For descriptive analyses, we defined 4 age groups: 45-70, 70$80,80-90$, and $90-100$ years of age. We used a multistate modeling approach to estimate transition rates and estimated and extrapolated the mean time of a person in each care state. ${ }^{18,19}$ This approach incorporates the complete care trajectory and considers all transitions simultaneously, thereby providing an advantage over separate survival models for each transition. ${ }^{20}$ We used the $m s m \mathrm{R}$ package (Christopher Jackson, https://github.com/chjackson/msm) to develop a continuous-time illness-to-death model with age centered at the sample mean age of 80 years as time scale. ${ }^{18}$ For each demographical or health-related factor, we computed hazard ratios (HRs) for the different transition rates. First, we fitted a model containing age and sex only (model 1 ). Next, we extended the model with polypharmacy, dementia medication, and living situation (model 2). Then, migration background and income effects on dementia care transition rates were tested with models including only age and sex (model 3 and 4, respectively), because the prevalence of a non-Western migration background was low and income was only available for a subgroup. We used the Estimation of Life Expectancies using Continuous-Time multistate survival models' package in $\mathrm{R}^{19}$ to estimate duration of care states and demographics and health-related factor effects on estimated care state duration.

\section{Model Performance}

To internally validate our dementia care model, we compared observed with expected year-specific prevalence estimates (Supplementary Figure 2). The difference between observed and predicted values was less than $10 \%$ in $71 \%$ of comparisons. Mortality was overestimated (11.4\% after 3 years to $13.9 \%$ after 6 years) and home care was underestimated (10.5\% after 4 years to $16.7 \%$ after 6 years).

\section{Results}

\section{Sample Characteristics}

In our sample of 11,012 persons with dementia, baseline age was 79.8 (SD 8.0) years and 61\% were women. Sample characteristics by age groups are shown in Table 1. Mean follow-up time was 1.93.1 years. With increasing age, the relative proportion of women, persons living alone, and persons with polypharmacy increased. Persons with dementia in the oldest age group received $\sim 4.5$ times more often home care during diagnosis than the youngest age group. During follow-up, the proportion of persons receiving home care and institutional care increased as expected. Mortality during follow-up increased from $13 \%$ in the group age $45-70$ years to $45 \%$ in the oldest group.

\section{Care Transition Rates}

Higher age was associated with higher probabilities of mortality and transitions to more care-intensive states. Men had a lower probability (HR 0.92) of transitioning from no formal care to home care and a higher probability of mortality when receiving home care (HR 2.16) or institutional care (HR 1.84) compared with women. Table 2 shows all care transition rates and HRs of demographic and health-related factors on each care transition.

Table 1

Sample Characteristics

\begin{tabular}{|c|c|c|c|c|}
\hline Baseline Characteristics & $45-70$ y n $=1040$ & $70-80$ y n $=3471$ & $80-90$ y n $=5423$ & $90-100$ y n $=1078$ \\
\hline Age, y mean (SD) & $62.4(4.9)$ & $74.9(2.8)$ & $83.6(2.7)$ & $91.9(2.3)$ \\
\hline Women, \% & 49 & 55 & 64 & 71 \\
\hline Polypharmacy, \% & 57 & 70 & 75 & 73 \\
\hline Living alone, $\%$ & 21 & 33 & 52 & 70 \\
\hline Prescribed dementia medication, \% & 16 & 17 & 12 & 6 \\
\hline Non-Western migration background, \% & 9 & 4.5 & 1.6 & 1.2 \\
\hline Higher income, ${ }^{*} \%$ & 58 & 52 & 51 & 48 \\
\hline Home care, \% & 14 & 28 & 51 & 67 \\
\hline \multicolumn{5}{|l|}{ During follow-up } \\
\hline Mean follow-up time, y & 3.1 & 3.0 & 2.6 & 1.9 \\
\hline No formal care use beside GP care, \% & 47 & 27 & 14 & 10 \\
\hline Home care, $\%$ & 51 & 70 & 83 & 88 \\
\hline Institutional care, \% & 17 & 28 & 34 & 34 \\
\hline Mortality, \% & 13 & 20 & 32 & 45 \\
\hline \multicolumn{5}{|l|}{ Number of care transitions, ${ }^{\dagger} \%$} \\
\hline 0 transitions & 53 & 39 & 37 & 44 \\
\hline 1 transition & 23 & 31 & 37 & 39 \\
\hline 2 transitions & 15 & 20 & 16 & 11 \\
\hline 3 or more transitions & 9 & 10 & 9 & 6 \\
\hline
\end{tabular}

SD, standard deviation.

Characteristics are shown for persons with dementia across different age groups: 45-70, 70-80, 80-90, and 90-100 years.

*Income was available for 10.979 persons.

${ }^{\dagger}$ Number of care transitions including transitions from transient states back to less care-intensive transient states, excluding transitions to death. 
Table 2

Transition Rates and HRs for the Different Demographic Factors and Health-Related Factors on Each Dementia Care Transition

\begin{tabular}{|c|c|c|c|c|c|c|c|c|c|}
\hline & $\begin{array}{l}\text { No Formal } \\
\text { Care to } \\
\text { Home Care }\end{array}$ & $\begin{array}{l}\text { No Formal } \\
\text { Care to } \\
\text { Institutional } \\
\text { Care }\end{array}$ & $\begin{array}{l}\text { No Formal } \\
\text { Care } \\
\text { to Death }\end{array}$ & $\begin{array}{l}\text { Home Care } \\
\text { to No } \\
\text { Formal } \\
\text { Care }\end{array}$ & $\begin{array}{l}\text { Home Care } \\
\text { to Institutional } \\
\text { Care }\end{array}$ & $\begin{array}{l}\text { Home Care to } \\
\text { Death }\end{array}$ & $\begin{array}{l}\text { Institutional } \\
\text { Care to No } \\
\text { Formal Care }\end{array}$ & $\begin{array}{l}\text { Institutional } \\
\text { Care to } \\
\text { Home Care }\end{array}$ & $\begin{array}{l}\text { Institutional } \\
\text { Care to Death }\end{array}$ \\
\hline \multicolumn{10}{|l|}{ Model 1 - Age, sex } \\
\hline Baseline transition rate, at age $80 \mathrm{y}$ & 0.43 & 0.05 & 0.04 & 0.20 & 0.22 & 0.05 & 0.07 & 0.02 & 0.20 \\
\hline HR age, per $1-y$ increase & $1.04^{* *}$ & $1.05^{* *}$ & $1.12^{* *}$ & $0.98^{* *}$ & $1.03^{* *}$ & $1.07^{* *}$ & $0.97^{* *}$ & $0.96^{* *}$ & $1.04^{* *}$ \\
\hline HR male sex & $0.92^{*}$ & 0.93 & 1.07 & $1.16^{* *}$ & 1.05 & $2.16^{* *}$ & 1.10 & 1.41 & $1.84^{* *}$ \\
\hline \multicolumn{10}{|c|}{ Model 2 - Age, sex, polypharmacy, living situation, dementia medication } \\
\hline Baseline transition rate, at age $80 \mathrm{y}$ & 0.37 & 0.04 & 0.03 & 0.22 & 0.26 & 0.05 & 0.04 & 0.03 & 0.22 \\
\hline HR age, per $1-y$ increase & $1.03^{* *}$ & $1.05^{* *}$ & $1.11^{* *}$ & $0.98^{* *}$ & $1.03^{* *}$ & $1.07^{* *}$ & $0.97^{* *}$ & $0.97^{*}$ & $1.04^{* *}$ \\
\hline HR male sex & 0.95 & 1.04 & $1.27^{*}$ & 1.08 & 1.02 & $1.9^{* *}$ & 1.02 & 1.14 & $1.69^{* *}$ \\
\hline HR polypharmacy & $1.08^{*}$ & 1.00 & $1.48^{* *}$ & 1.02 & $0.87^{* *}$ & $1.39^{* *}$ & $1.97^{* *}$ & 1.33 & 1.01 \\
\hline HR living alone & $1.15^{* *}$ & $1.43^{* *}$ & $1.62^{* *}$ & $0.80^{* *}$ & $0.90^{*}$ & $0.72^{* *}$ & 0.83 & $0.50^{* *}$ & $0.80^{* *}$ \\
\hline HR dementia medication & $1.23^{* *}$ & 1.27 & 1.00 & 0.96 & $1.15^{*}$ & $0.78^{*}$ & 1.01 & 0.73 & 1.03 \\
\hline \multicolumn{10}{|c|}{ Model 3 - Age, sex, migration background } \\
\hline Baseline transition rate, at age $80 \mathrm{y}$ & 0.33 & 0.04 & 0.07 & 0.30 & 0.12 & 0.04 & 0.15 & 0.02 & 0.16 \\
\hline HR age, per $1-y$ increase & $1.04^{* *}$ & $1.05^{* *}$ & $1.12^{* *}$ & $0.98^{* *}$ & $1.02^{* *}$ & $1.07^{* *}$ & $0.97^{* *}$ & $0.96^{* *}$ & $1.04^{* *}$ \\
\hline HR male sex & $0.91^{* *}$ & 0.93 & 1.07 & $1.15^{* *}$ & 1.06 & $2.16^{* *}$ & 1.10 & 1.41 & $1.84^{* *}$ \\
\hline HR Western migration background & $1.31^{* *}$ & 1.17 & $0.66^{*}$ & $0.63^{* *}$ & $1.86^{* *}$ & 1.21 & $0.38^{* *}$ & 0.98 & 1.20 \\
\hline \multicolumn{10}{|l|}{ Model 4 - Age, sex, income } \\
\hline Baseline transition rate, at age $80 \mathrm{y}$ & 0.45 & 0.05 & 0.05 & 0.19 & 0.23 & 0.05 & 0.05 & 0.02 & 0.20 \\
\hline HR age, per $1-y$ increase & $1.04^{* *}$ & $1.05^{* *}$ & $1.12^{* *}$ & $0.98^{* *}$ & $1.03^{* *}$ & $1.07^{* *}$ & $0.97^{* *}$ & $0.96^{* *}$ & $1.04^{* *}$ \\
\hline HR male sex & $0.92^{* *}$ & 0.95 & 1.09 & $1.15^{* *}$ & 1.06 & $2.13^{* *}$ & 1.07 & 1.37 & $1.84^{* *}$ \\
\hline HR higher income & $0.89^{* *}$ & $0.69^{* *}$ & $0.76^{* *}$ & $1.12^{* *}$ & 0.97 & 1.11 & $1.55^{* *}$ & $1.55^{*}$ & 0.95 \\
\hline
\end{tabular}

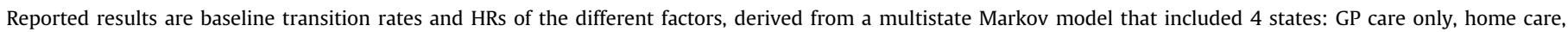

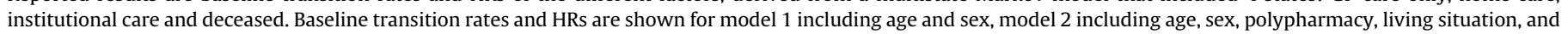
dementia medication, model 3 including age, sex, and migration background and model 4 including age, sex, and income.

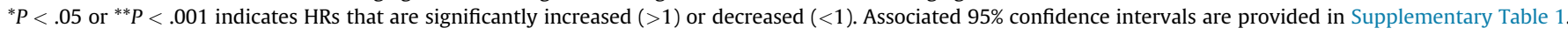

Associated confidence intervals are provided in Supplementary Table 1.

\section{Dementia Care Duration}

Figure 1 (Supplementary Table 2) shows the estimated duration of care types for men and women of different ages. From diagnosis onwards, mean duration without formal care at age 85 was 0.7 years in men and 0.8 years in women, home care duration was 1.7 years in men and 2.3 years in women, and institutional care duration was 1.1 years in men and 2.3 years in women. With increasing age in both men and women, the duration without formal care became shorter, while home care and institutional care became longer. Home and institutional care duration was longer in women compared with men. In men, home care duration was relatively long. In women, the duration without formal care was relatively short.

The influence of polypharmacy, living situation, and dementia medication on the estimated duration of care types is shown in Supplementary Table 3. Persons without polypharmacy had a longer institutional care and total duration compared with persons with polypharmacy. Persons living alone had a shorter duration without formal care than persons not living alone.

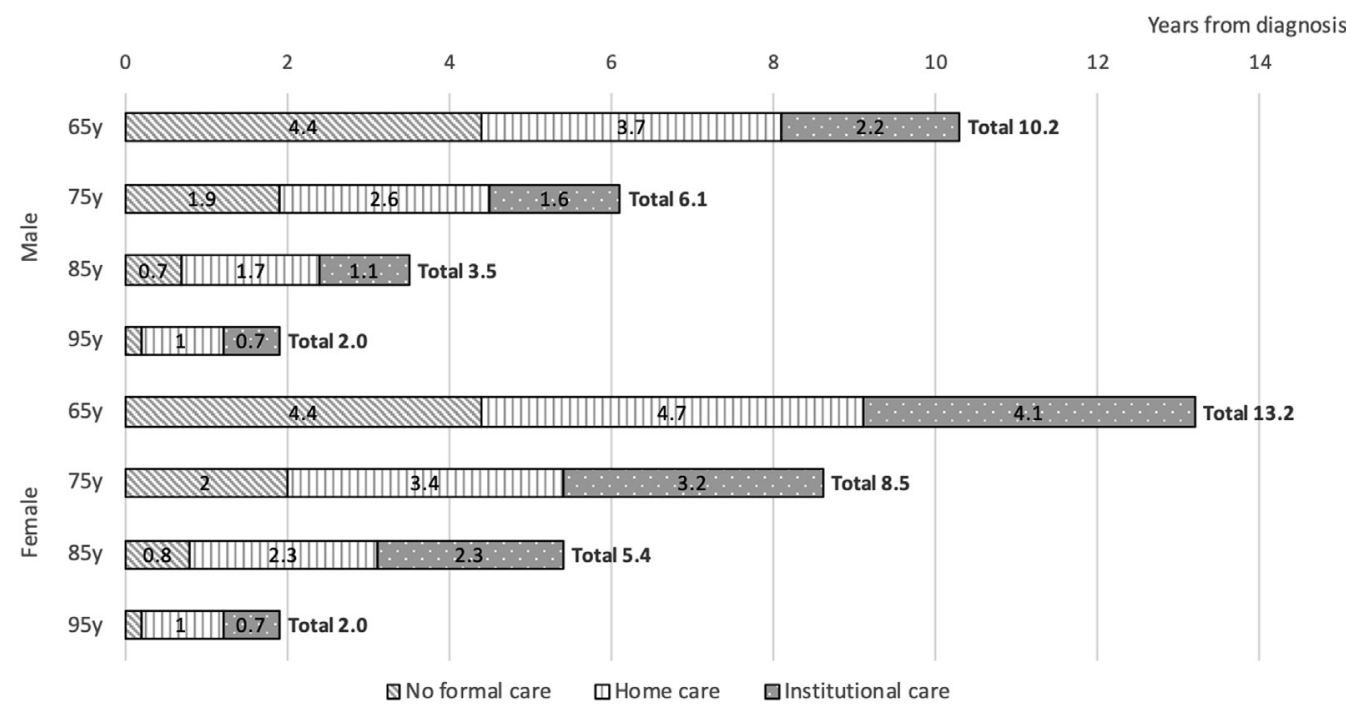

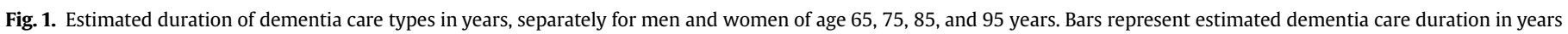

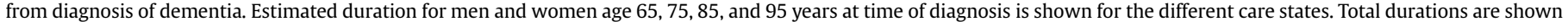
in bold. 
Persons without prescribed dementia medication had a longer duration without formal care compared to persons with dementia medication.

Persons with a non-Western migration background had a longer duration without formal care, but a shorter institutional care duration while total care duration was longer compared with persons with a Western background (Supplementary Table 4). Persons with a higher income had a longer duration without formal care and a longer total duration compared with persons with a lower income (Supplementary Table 4).

\section{Discussion}

The present study describes the duration of different formal care types and the influence of demographic and clinical characteristics on care duration in a large sample of persons with dementia in the Netherlands. Our total dementia care duration of 6.1-8.5 years in 75 -year-olds is in accordance with a retrospective medical records study. ${ }^{5}$ However, a previous primary care study found a shorter total estimated dementia duration in 65-year-olds compared with our study (6.7 years in persons age 60-69 vs 10.2 and 13.2 years for 65year-old men and women, respectively). ${ }^{8}$ This could partly be explained by differences in statistical approach (survival analysis vs multistate modeling), setting and care system, or assessment time (1990-2007 vs 2008-2014). Interestingly, our care duration estimates in persons with dementia (ie, remaining life-expectancy from diagnosis onwards) are shorter than life-expectancies in the general Dutch population $^{21}$ (Supplementary Figure 3).

Several factors influenced the duration of formal care types. In accordance with most previous studies, older age and male sex were associated with shorter total care duration. ${ }^{22-25}$ Presumably, this shorter duration in older men can be explained by a shorter life expectancy in men compared with women. ${ }^{3}$ Total care duration (ie, survival from diagnosis onwards) was shortest in persons with polypharmacy, which fits with associations of polypharmacy with more extensive care dependency and frailty. ${ }^{26,27}$ Living alone was associated with a shorter duration without formal care and longer home and institutional care duration, and longer total duration, which is in accordance with previous studies and might be explained by a lack of informal caregiving at home and resulting in increased use of formal services in persons living alone. ${ }^{28,29}$ This underscores the importance of social support networks for persons living with dementia. Prescribed dementia medication was associated with a shorter duration without formal care and overall duration. This is inconsistent with previous results indicating a dose-dependent relationship between dementia medication and home care amount ${ }^{30}$ or postponed institutional care, ${ }^{9}$ but is consistent with other studies where institutional care duration was not influenced by dementia medication. ${ }^{10}$ Dementia medication prescription and reimbursement in the Netherlands is dependent on dementia severity, ${ }^{31}$ and our results might have been influenced by differing dementia severity in persons with and without dementia medication. The longer duration without formal care in persons with a non-Western migration background might be explained by an influence of cultural differences in informal family caregiving on formal healthcare use. ${ }^{13,32}$ Higher income was associated with a longer duration without formal care, which is in line with previously reported associations of lower income with poorer health status and, thus, increased formal care needs. ${ }^{33}$ However, lower income has also been identified as a barrier to institutionalization, ${ }^{34}$ and access to care may be of influence.

\section{Strengths and Limitations}

The present study has several strengths. To the best of our knowledge, this is the first study on formal care duration and its determinants across the full dementia care trajectory from diagnosis to death in a registry-based sample. By using long-term information of a large population of patients from a broad GP sample in combination with nationwide registries, we have been able to estimate the duration of care types and the role of potential factors of influence reliably, and to minimize potential selection and attrition biases.

This study also has limitations. As is typically the case in data registries, no information was available on dementia severity, dementia subtype, informal care use, need for care, and indication for care use. Results may be applicable only in the Netherlands because of differences in care organization, capacity, and access. However, the impact of most of our predictors on care duration may be similar across care systems. Furthermore, we included patients with a dementia diagnosis recorded by their GP, and underreporting is possible. A dementia diagnosis may not have been recorded in some patients when other diagnoses were considered of greater importance and for persons with uncertain mild dementia. This potential underreporting might have resulted in fewer mild dementia cases in our sample and overestimation of care use. Alternatively, this might have resulted in increased frailty and comorbidities and underestimation of care use. This makes it difficult to estimate the impact of this underreporting. However, we did incorporate knowledge on data quality within the registry as well as data-recording setting, ${ }^{35}$ and the registry is increasingly used for communication between healthcare professionals and for patient management. ${ }^{36}$ Because day care use was not registered before 2011, home care may have been underreported before 2011. However, the number of persons receiving only day care, without additional home care types, was small (approximately $2 \%$ per year). Also, we included baseline health-related factors, and future studies should incorporate these characteristics as time-varying factors. Furthermore, palliative care impact on care trajectories could not be assessed due to limited information in the registry. Palliative care is registered since 2011 as a separate institutional care type and, because it was provided to a very small proportion of all registrations between 2011 and 2014, we expect its impact to be limited. Also, age was used as a time-scale to account for progression risk changes with age, but possible nonlinear age effects were not addressed.

\section{Conclusions and Implications}

Our findings increase understanding of long-term dementia care trajectories and show that the duration without formal care was longer in persons not living alone, without prescribed dementia medication, with a non-Western migration background, or with a higher income. Home or institutional care duration was longer in women, persons without polypharmacy, in those living alone, or those with a Western background. Our results demonstrate the value of unbiased, real-life care trajectories for visualizing individual variations and are thus important for healthcare policy decisions. Our estimates of the duration of different care types could help healthcare professionals to provide a prognosis of the care trajectory, which might aid timely care planning. Furthermore, our insights regarding care transitions could be valuable for policymakers in examining potential care organization improvements. As clinical practice is moving towards a more personalized approach, future studies should investigate how informal care, access to care, social support networks, psychological needs, dementia severity and subtype, and underlying pathology could further contribute to care duration.

\section{Supplementary Data}

Supplementary Data related to this article can be found online at https://doi.org/10.1016/j.jamda.2020.01.008. 


\section{References}

1. National Collaborating Centre for Mental H. National Institute for Health and Clinical Excellence: Guidance. In: Dementia: A NICE-SCIE Guideline on Supporting People With Dementia and Their Carers in Health and Social Care. Leicester (UK): British Psychological Society The British Psychological Society \& The Royal College of Psychiatrists; 2007.

2. Luppa M, Luck T, Brähler E, et al. Prediction of institutionalisation in dementia. Dement Geriatr Cogn Disord 2008;26:65-78.

3. Brodaty H, Seeher K, Gibson L. Dementia time to death: a systematic literature review on survival time and years of life lost in people with dementia. Int Psychogeriatr 2012:24:1034-1045.

4. Kua EH, Ho E, Tan HH, et al. The natural history of dementia. Psychogeriatrics 2014;14:196-201.

5. Jost BC, Grossberg GT. The natural history of Alzheimer's disease: A brain bank study. J Am Geriatr Soc 1995;43:1248-1255.

6. Coley N, Gallini A, Gares V, et al. A Longitudinal Study of Transitions Between Informal and Formal Care in Alzheimer Disease Using Multistate Models in the European ICTUS Cohort. J Am Med Dir Assoc 2015:16:1104 e1101-e1107.

7. Wimo A, Reed CC, Dodel R, et al. The GERAS Study: a prospective observational study of costs and resource use in community dwellers with Alzheimer's disease in three European countries-Study design and baseline findings. J Alzheimers Dis 2013;36:385-399.

8. Rait G, Walters K, Bottomley C, et al. Survival of people with clinical diagnosis of dementia in primary care: cohort study. BMJ 2010;341:c3584.

9. Wattmo C, Wallin AK, Londos E, Minthon L. Risk factors for nursing home placement in Alzheimer's disease: A longitudinal study of cognition, ADL, service utilization, and cholinesterase inhibitor treatment. Gerontologist 2011; 51:17-27.

10. Wattmo C, Londos E, Minthon L. Cholinesterase inhibitors do not alter the length of stay in nursing homes among patients with Alzheimer's disease: A prospective, observational study of factors affecting survival time from admission to death. BMC Neurol 2016;16:156.

11. Wattmo C, Londos E, Minthon L. Risk factors that affect life expectancy in Alzheimer's disease: A 15-year follow-up. Dement Geriatr Cogn Disord 2014; 38:286-299.

12. Mukadam N, Cooper C, Livingston G. Improving access to dementia services for people from minority ethnic groups. Curr Opin Psychiatry 2013;26:409.

13. Kosloski K, Schaefer JP, Allwardt D, et al. The role of cultural factors on clients' attitudes toward caregiving, perceptions of service delivery, and service utilization. Home Health Care Serv Q 2002;21:65-88.

14. Boersma-van Dam MEWY, Hek K, Davids RN, et al. Zorg door de huisarts. Uit: Zorg door de huisarts - Nivel Zorgregistraties eerste lijn: Jaarcijfers 2017 en trendcijfers 2011-2017. Verantwoording cijfers huisartsenzorg. Uit: NIVEL Zorgregistraties eerste lijn [internet]. 2019. Updated 25-01-2019. www.nivel. nl/nl/zorgregistraties-eerste-lijn/huisartsen. Accessed May 13, 2019.

15. Bentsen BG. International classification of primary care. Scand J Prim Health Care 1986;4:43-50.

16. Bakker BFM, van Rooijen J, van Toor L. The System of social statistical datasets of Statistics Netherlands: An integral approach to the production of registerbased social statistics. Stat J IAOS 2014;30:411-424.

17. Masnoon N, Shakib S, Kalisch-Ellett L, Caughey GE. What is polypharmacy? A systematic review of definitions. BMC Geriatr 2017;17:230.
18. Jackson CH. Multistate models for panel data: The msm package for R. J Stat Software 2011;38:1-29.

19. Van den Hout A, Sum Chan M. ELECT: Estimation of life expectancies using continuous-time multistate survival models; 2014. Available at: https://cran.rproject.org/web/packages/elect/index.html. Accessed February 10, 2020.

20. Meira-Machado L, de Una-Alvarez J, Cadarso-Suarez C, Andersen PK. Multistate models for the analysis of time-to-event data. Stat Methods Med Res 2009;18:195-222.

21. Netherlands S. Life expectancy by gender and age for the Dutch population. Central Bureau for Statistics. http://statline.cbs.nl/Statweb/publica tion $/$ ?WW $=\mathrm{T} \& \mathrm{DM}=\mathrm{SLNL} \& \mathrm{PA}=37360$ ned $\& \mathrm{D} 1=3 \& \mathrm{D} 2=\mathrm{a} \& \mathrm{D} 3=0,21,65,75,85$, $95 \& D 4=0,8,13,24,54,84,94 \& H D=190129-1251 \& H D R=G 1, T \& S T B=G 2, G 3$. Accessed January 29, 2019.

22. Jagger C, Clarke M, Stone A. Predictors of survival with Alzheimer's disease: a community-based study. Psychol Med 1995;25:171-177.

23. Ganguli M, Dodge HH, Shen C, et al. Alzheimer disease and mortality. A 15-year epidemiological study 2005;62:779-784.

24. Mölsä P, Marttila R, Rinne U. Long-term survival and predictors of mortality in Alzheimer's disease and multi-infarct dementia. Acta Neurol Scand 1995;91: $159-164$

25. Xie J, Brayne C, Matthews FEJB. Survival times in people with dementia: analysis from population based cohort study with 14 year follow-up. BMJ 2008;336:258-262.

26. Fried TR, O'leary J, Towle V, et al. Health outcomes associated with polypharmacy in community-dwelling older adults: A systematic review 2014;62: 2261-2272.

27. Gómez C, Vega-Quiroga S, Bermejo-Pareja F, et al. Polypharmacy in the elderly: A marker of increased risk of mortality in a population-based prospective study (NEDICES). Gerontology 2015;61:301-309.

28. Wimo A, von Strauss E, Nordberg G, et al. Time spent on informal and formal care giving for persons with dementia in Sweden. Health Policy 2002;61: 255-268.

29. Bergmann K, Foster EM, Justice A, Matthews V. Management of the demented elderly patient in the community. Br J Psychiatry 1978;132: 441-449.

30. Wattmo C, Paulsson E, Minthon L, Londos E. A longitudinal study of risk factors for community-based home help services in Alzheimer's disease: The influence of cholinesterase inhibitor therapy. Clin Intervent Aging 2013;8:329.

31. Olde Rikkert M, van Exel E, Knol W, et al. Richtlijn diagnostiek en behandeling van dementie. Ned Tijdschr Geneeskd 2015;159:A8671.

32. van Wezel N, Francke AL, Kayan-Acun E, et al. Family care for immigrants with dementia: The perspectives of female family carers living in The Netherlands. Dementia (London) 2016;15:69-84.

33. Benzeval M, Taylor J, Judge K. Evidence on the relationship between low income and poor health: Is the government doing enough? Fiscal Stud 2000;21: 375-399.

34. Van Doorslaer E, Masseria C, Koolman X. Inequalities in access to medical care by income in developed countries. CMAJ 2006;174:177-183.

35. Verheij RA, Curcin V, Delaney BC, McGilchrist MM. Possible sources of bias in primary care electronic health record data use and reuse. J Med Internet Res 2018;20:e185.

36. van der Bij S, Khan N, ten Veen P, et al. Improving the quality of EHR recording in primary care: A data quality feedback tool. J Am Med Inform Assoc 2016;24: $81-87$. 


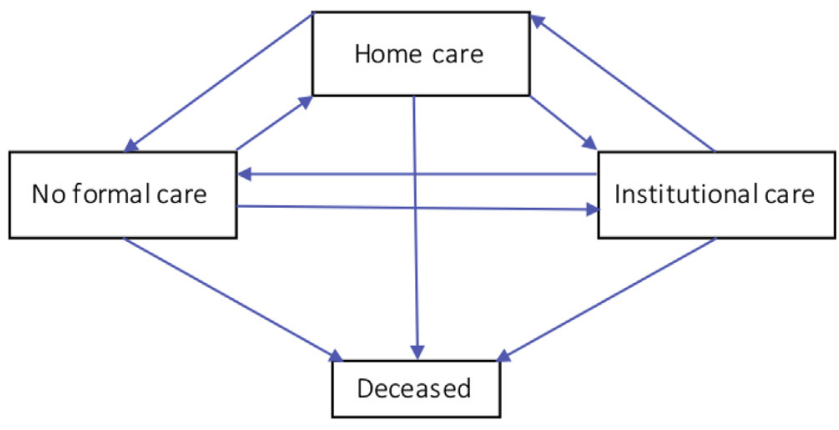

Supplementary Fig. 1. Visual representation of the dementia care multistate model with 3 transient states and death as end state. Arrows showing transitions between states, including transitions from transient states back to less severe transient states.
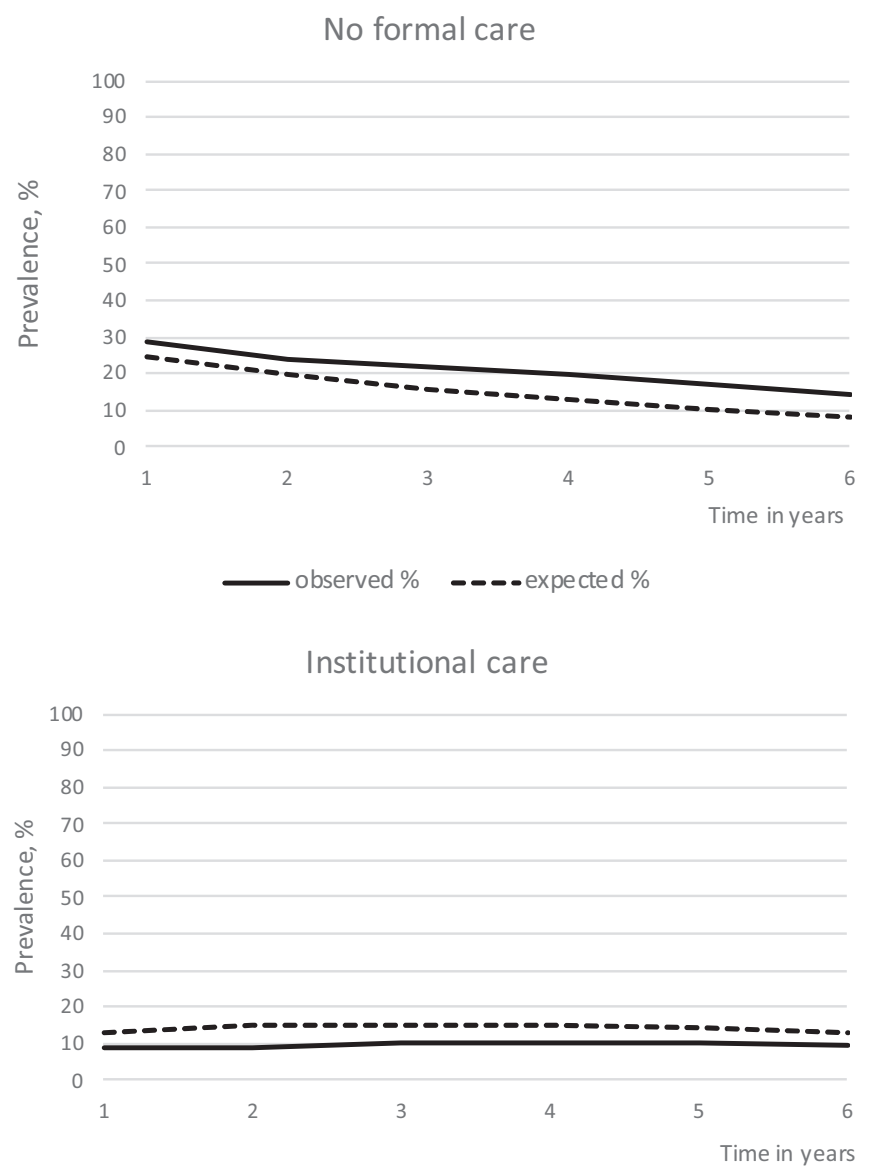

observed \% - - - expected \%
Home care

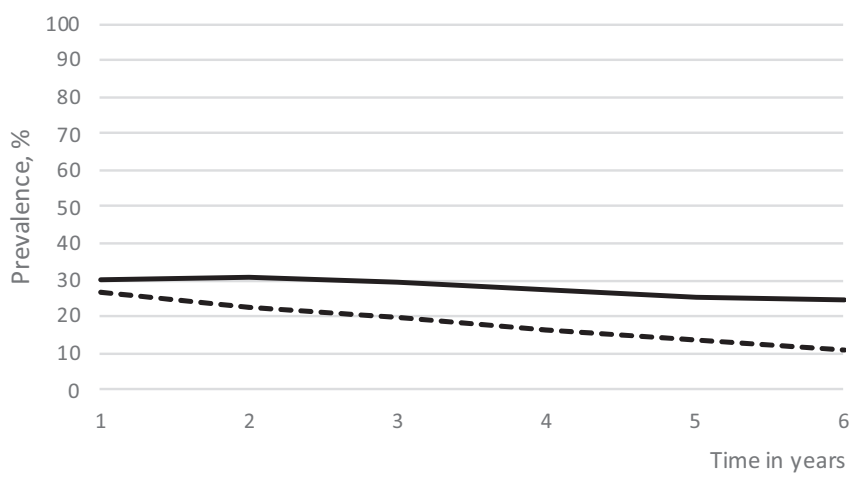

observed $\% \quad$ - - - expected $\%$

\section{Deceased}

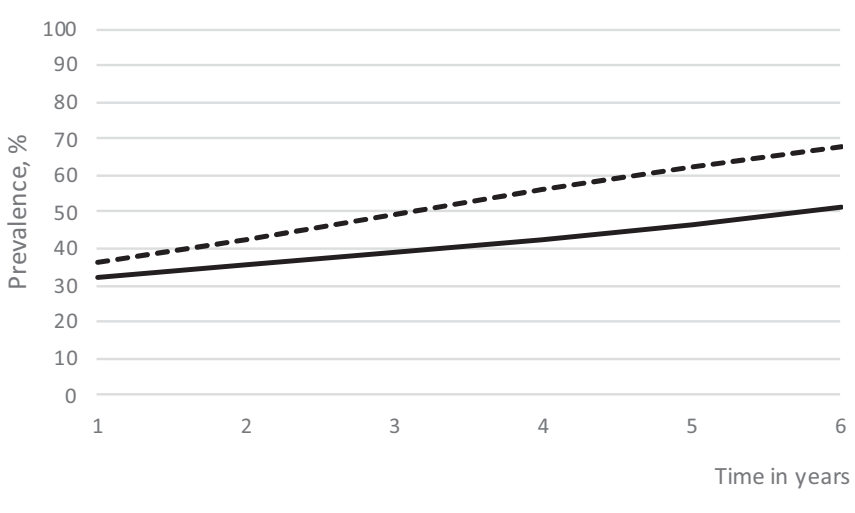

observed \% - - - - expected \%

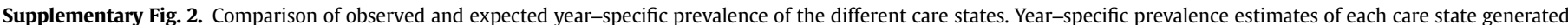

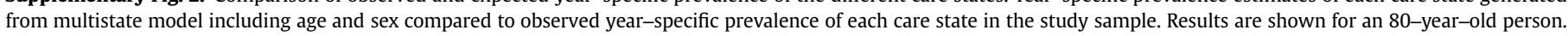
Estimates for the different states (no formal care, home care, institutional care and deceased) are shown in percentages for each year up to 6 years. 


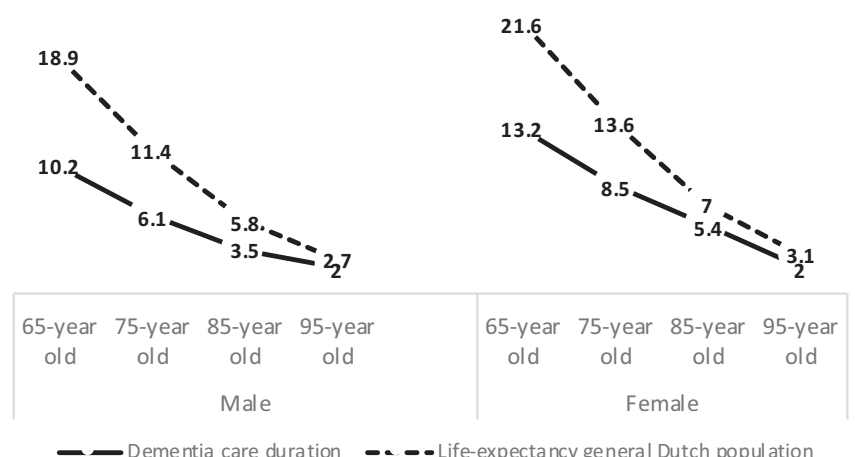

Supplementary Fig. 3. Comparison of estimated care durations in years in persons with dementia with life expectancies in the general Dutch population of men and women of different ages. Durations in years are shown for men and women age 65, 75, 85 , and 95 years. Life expectancy estimates of the general Dutch population were obtained from CBS Statline calculations from 2014. CBS, Statistics Netherlands.

Supplementary Table 1

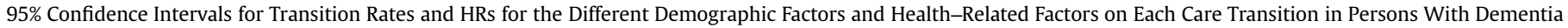

\begin{tabular}{|c|c|c|c|c|c|c|c|c|c|}
\hline & $\begin{array}{l}\text { No Formal Care } \\
\text { to Home Care }\end{array}$ & $\begin{array}{l}\text { No Formal } \\
\text { Care to } \\
\text { Institutional } \\
\text { Care }\end{array}$ & $\begin{array}{l}\text { No Formal } \\
\text { Care to Death }\end{array}$ & $\begin{array}{l}\text { Home Care } \\
\text { to No Formal } \\
\text { Care }\end{array}$ & $\begin{array}{l}\text { Home } \\
\text { Care to } \\
\text { Institutional } \\
\text { Care }\end{array}$ & $\begin{array}{l}\text { Home } \\
\text { Care to } \\
\text { Death }\end{array}$ & $\begin{array}{l}\text { Institutional } \\
\text { Care to No } \\
\text { Formal Care }\end{array}$ & $\begin{array}{l}\text { Institutional } \\
\text { Care to Home } \\
\text { Care }\end{array}$ & $\begin{array}{l}\text { Institutional } \\
\text { Care to Death }\end{array}$ \\
\hline \multicolumn{10}{|l|}{ Model 1 - Age, sex } \\
\hline $\begin{array}{l}\text { Baseline transition rate, } \\
\text { at age } 80 y\end{array}$ & $0.41-0.44$ & $0.04-0.05$ & $0.04-0.05$ & $0.19-0.21$ & $0.21-0.24$ & $0.05-0.06$ & $0.05-0.07$ & $0.02-0.03$ & $0.18-0.21$ \\
\hline HR age, per $1-\mathrm{y}$ increase & $1.03-1.04$ & $1.04-1.06$ & $1.11-1.13$ & $0.98-0.98$ & $1.02-1.03$ & $1.06-1.08$ & $0.95-0.99$ & $0.94-0.99$ & $1.03-1.05$ \\
\hline HR male sex & $0.86-0.97$ & $0.78-1.10$ & $0.91-1.25$ & $1.07-1.26$ & $0.98-1.14$ & $1.92-2.43$ & $0.98-1.43$ & $0.93-2.13$ & $1.65-2.06$ \\
\hline \multicolumn{10}{|c|}{ Model 2 - Age, sex, polypharmacy, living situation, dementia medication } \\
\hline $\begin{array}{l}\text { Baseline transition } \\
\text { rate, at age } 80 \mathrm{y}\end{array}$ & $0.35-0.39$ & $0.03-0.05$ & $0.02-0.03$ & $0.20-0.24$ & $0.24-0.28$ & $0.04-0.06$ & $0.03-0.06$ & $0.02-0.04$ & $0.19-0.25$ \\
\hline HR age, per $1-\mathrm{y}$ increase & $1.03-1.04$ & $1.04-1.06$ & $1.10-1.12$ & $0.98-0.99$ & $1.02-1.03$ & $1.06-1.09$ & $0.95-0.99$ & $0.94-0.99$ & $1.03-1.05$ \\
\hline HR male sex & $0.89-1.01$ & $0.86-1.26$ & $1.07-1.17$ & $0.99-1.17$ & $0.94-1.11$ & $1.67-2.15$ & $0.78-1.34$ & $0.74-1.76$ & $1.50-1.91$ \\
\hline HR polypharmacy & $1.01-1.15$ & $0.84-1.20$ & $1.23-1.77$ & $0.93-1.11$ & $0.80-0.94$ & $1.20-1.61$ & $1.43-2.71$ & $0.83-2.12$ & $0.89-1.14$ \\
\hline HR living alone & $1.08-1.23$ & $1.18-1.73$ & $1.36-1.93$ & $0.73-0.87$ & $0.84-0.98$ & $0.63-0.81$ & $0.64-1.08$ & $0.32-0.79$ & $0.80-0.90$ \\
\hline HR dementia medication & $1.14-1.33$ & $1.00-1.61$ & $0.78-1.28$ & $0.86-1.08$ & $1.04-1.27$ & $0.64-0.95$ & $0.73-1.39$ & $0.40-1.31$ & $0.88-1.20$ \\
\hline \multicolumn{10}{|c|}{ Model 3 - Age, sex, migration background } \\
\hline $\begin{array}{l}\text { Baseline transition } \\
\text { rate, at age } 80 \mathrm{y}\end{array}$ & $0.28-0.39$ & $0.02-0.06$ & $0.05-0.10$ & $0.25-0.37$ & $0.09-0.17$ & $0.03-0.07$ & $0.09-0.27$ & $0.01-0.08$ & $0.10-0.27$ \\
\hline HR age, per 1-year increase & $1.03-1.04$ & $1.04-1.06$ & $1.11-1.13$ & $0.98-0.99$ & $1.02-1.03$ & $1.06-1.08$ & $0.96-0.99$ & $0.94-0.99$ & $1.03-1.05$ \\
\hline HR male sex & $0.86-0.97$ & $0.78-1.10$ & $0.91-1.25$ & $1.06-1.25$ & $0.98-1.14$ & $1.92-2.43$ & $0.85-1.43$ & $0.93-2.14$ & $1.65-2.06$ \\
\hline $\begin{array}{l}\text { HR Western migration } \\
\text { background }\end{array}$ & $1.11-1.53$ & $0.73-1.87$ & $0.46-0.94$ & $0.52-0.76$ & $1.35-2.55$ & $0.76-1.92$ & $0.22-0.68$ & $0.24-4.05$ & $0.71-2.04$ \\
\hline \multicolumn{10}{|l|}{ Model 4 - Age, sex, income } \\
\hline $\begin{array}{l}\text { Baseline transition } \\
\text { rate, at age } 80 \mathrm{y}\end{array}$ & $0.43-0.47$ & $0.05-0.06$ & $0.04-0.06$ & $0.17-0.20$ & $0.21-0.24$ & $0.04-0.06$ & $0.04-0.06$ & $0.01-0.02$ & $0.18-1.04$ \\
\hline $\begin{array}{l}\text { HR age, per 1-year } \\
\text { increase }\end{array}$ & $1.03-1.04$ & $1.04-1.06$ & $1.10-1.13$ & $0.97-0.98$ & $1.02-1.03$ & $1.06-1.08$ & $0.95-0.99$ & $0.94-0.99$ & $1.03-1.05$ \\
\hline HR male sex & $0.87-0.97$ & $0.80-1.13$ & $0.93-1.28$ & $1.06-1.24$ & $0.98-1.14$ & $1.89-2.40$ & $0.82-1.38$ & $0.90-2.07$ & $1.65-2.06$ \\
\hline HR higher income & $0.85-0.95$ & $0.58-0.82$ & $0.65-0.89$ & $1.04-1.21$ & $0.90-1.04$ & $0.98-1.25$ & $1.21-1.98$ & $1.03-2.33$ & $0.85-1.07$ \\
\hline
\end{tabular}

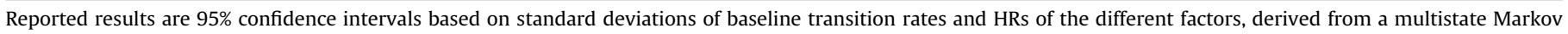

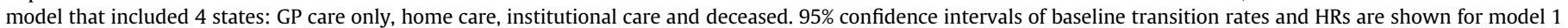

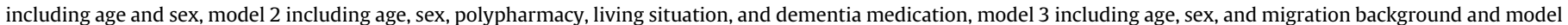
4 including age, sex, and income. 
Supplementary Table 2

Estimated Dementia Care Durations in Years for Men and Women of Different Ages

\begin{tabular}{|c|c|c|c|c|}
\hline Age & No Formal Care & Home Care & Institutional Care & Total Duration \\
\hline \multicolumn{5}{|l|}{ Male } \\
\hline $65 \mathrm{y}$ & $4.4(4.1-4.7)$ & $3.7(3.4-3.9)^{*}$ & $2.2(1.9-2.4)^{*}$ & $10.2(9.7-10.7)^{*}$ \\
\hline $75 \mathrm{y}$ & $1.9(1.8-2.0)$ & $2.6(2.4-2.7)^{*}$ & $1.6(1.5-1.8)^{*}$ & $6.1(5.9-6.4)^{*}$ \\
\hline $85 \mathrm{y}$ & $0.7(0.7-0.8)$ & $1.7(1.6-1.8)^{*}$ & $1.1(1.0-1.2)^{*}$ & $3.5(3.4-3.7)^{*}$ \\
\hline $95 \mathrm{y}$ & $0.2(0.2-0.3)$ & $1.0(0.9-1.1)^{*}$ & $0.7(0.6-0.8)^{*}$ & $2.0(1.8-2.2)^{*}$ \\
\hline \multicolumn{5}{|l|}{ Female } \\
\hline $65 \mathrm{y}$ & $4.4(4.1-4.7)$ & $4.7(4.4-5.0)^{*}$ & $4.1(3.7-4.4)^{*}$ & $13.2(12.6-13.8)^{*}$ \\
\hline $75 \mathrm{y}$ & $2.0(1.9-2.1)$ & $3.4(3.3-3.5)^{*}$ & $3.2(3.0-3.4)^{*}$ & $8.5(8.2-8.8)^{*}$ \\
\hline $85 \mathrm{y}$ & $0.8(0.7-0.8)$ & $2.3(2.2-2.4)^{*}$ & $2.3(2.1-2.5)^{*}$ & $5.4(5.2-5.7)^{*}$ \\
\hline $95 \mathrm{y}$ & $0.2(0.2-0.3)$ & $1.0(0.9-1.1)^{*}$ & $0.7(0.6-0.8)^{*}$ & $2.0(1.8-2.2)^{*}$ \\
\hline
\end{tabular}

Results are estimated durations of dementia care in years with $95 \%$ confidence intervals based on standard deviations of estimated durations. Estimated durations for men and women age $65,75,85$, and 95 years at time of diagnosis are shown for the different care states as well as total duration.

${ }^{*} P<.001$ indicates different duration estimates from estimates of women. 
Supplementary Table 3

Estimated Dementia Care Durations in Years by (A) Polypharmacy, (B) Living Situation, and (C) Dementia Medication, for Men and Women of Different Ages

\begin{tabular}{|c|c|c|c|c|}
\hline (A) Polypharmacy & No Formal Care & Home Care & Institutional Care & Total Duration \\
\hline \multicolumn{5}{|l|}{ Male, age } \\
\hline \multicolumn{5}{|l|}{$65 \mathrm{y}$} \\
\hline Polypharmacy & $4.6(4.3-5.0)$ & $3.7(3.4-3.9)$ & $1.9(1.7-2.1)^{*}$ & $10.2(9.6-10.7)$ \\
\hline No polypharmacy & $4.6(4.2-5.1)$ & $3.4(3.2-3.7)$ & $2.4(2.1-2.7)$ & $10.4(9.7-11.1)$ \\
\hline \multicolumn{5}{|l|}{$75 \mathrm{y}$} \\
\hline Polypharmacy & $2.0(1.9-2.2)$ & $2.5(2.4-2.7)$ & $1.4(1.3-1.5)^{*}$ & $6.0(5.7-6.2)$ \\
\hline No polypharmacy & $2.1(1.9-2.3)$ & $2.4(2.3-2.6)$ & $1.7(1.6-2.0)$ & $6.3(5.9-6.7)$ \\
\hline \multicolumn{5}{|l|}{$85 \mathrm{y}$} \\
\hline Polypharmacy & $0.8(0.7-0.9)$ & $1.6(1.5-1.7)$ & $1.0(0.9-1.1)^{*}$ & $3.3(3.1-3.5)^{*}$ \\
\hline No polypharmacy & $0.8(0.8-0.9)$ & $1.6(1.5-1.8)$ & $1.2(1.0-1.4)$ & $3.7(3.4-4.0)$ \\
\hline \multicolumn{5}{|l|}{$95 \mathrm{y}$} \\
\hline Polypharmacy & $0.3(0.2-0.3)$ & $0.9(0.8-1.0)$ & $0.6(0.5-0.7)$ & $1.8(1.6-1.9)^{*}$ \\
\hline No polypharmacy & $0.3(0.3-0.4)$ & $1.0(0.9-1.1)$ & $0.8(0.6-0.9)$ & $2.1(1.8-2.3)$ \\
\hline \multicolumn{5}{|l|}{ Female, age } \\
\hline \multicolumn{5}{|l|}{$65 \mathrm{y}$} \\
\hline Polypharmacy & $5.0(4.6-5.5)$ & $4.7(4.3-5.1)$ & $3.3(2.9-3.6)^{*}$ & $13.0(12.3-13.7)$ \\
\hline No polypharmacy & $4.8(4.3-5.3)$ & $4.1(3.8-4.6)$ & $4.0(3.5-4.6)$ & $12.9(12.2-13.8)$ \\
\hline \multicolumn{5}{|l|}{$75 \mathrm{y}$} \\
\hline Polypharmacy & $2.3(2.2-2.5)$ & $3.3(3.1-3.5)$ & $2.6(2.3-2.8)^{*}$ & $8.1(7.7-8.6)$ \\
\hline No polypharmacy & $2.2(2.0-2.5)$ & $3.0(2.8-3.2)$ & $3.1(2.7-3.5)$ & $8.3(7.8-8.9)$ \\
\hline \multicolumn{5}{|l|}{$85 \mathrm{y}$} \\
\hline Polypharmacy & $0.9(0.9-1.0)$ & $2.1(2.0-2.3)$ & $1.8(1.6-2.0)^{*}$ & $4.9(4.6-5.2)$ \\
\hline No polypharmacy & $0.9(0.9-1.1)$ & $2.0(1.9-2.2)$ & $2.2(1.9-2.5)$ & $5.2(4.8-5.6)$ \\
\hline \multicolumn{5}{|l|}{$95 \mathrm{y}$} \\
\hline Polypharmacy & $0.3(0.3-0.4)$ & $1.3(1.2-1.5)$ & $1.2(1.0-1.4)$ & $2.9(2.6-3.2)$ \\
\hline No polypharmacy & $0.4(0.3-0.4)$ & $1.3(1.2-1.5)$ & $1.5(1.2-1.8)$ & $3.2(2.9-3.5)$ \\
\hline (B) Living Situation & No formal care & Home care & Institutional care & Total duration \\
\hline Male, age & & & & \\
\hline $65 \mathrm{y}$ & & & & \\
\hline Living alone & $3.6(3.2-4.0)^{* *}$ & $3.8(3.5-4.2)$ & $3.1(2.6-3.6)^{*}$ & $10.5(9.8-11.3)$ \\
\hline Not living alone & $4.6(4.2-5.0)$ & $3.4(3.2-3.7)$ & $2.4(2.0-2.7)$ & $10.4(9.7-11.0)$ \\
\hline $75 \mathrm{y}$ & & & & \\
\hline Living alone & $1.6(1.5-1.8)^{* *}$ & $2.8(2.5-3.0)^{*}$ & $2.3(2.0-2.6)^{*}$ & $6.6(6.2-7.1)$ \\
\hline Not living alone & $2.1(1.9-2.3)$ & $2.4(2.3-2.6)$ & $1.7(1.6-2.0)$ & $6.3(5.9-6.7)$ \\
\hline $85 \mathrm{y}$ & & & & \\
\hline Living alone & $0.6(0.6-0.7)^{* *}$ & $1.9(1.7-2.1)^{*}$ & $1.6(1.3-1.8)^{*}$ & $4.1(3.8-4.4)$ \\
\hline Not living alone & $0.8(0.8-0.9)$ & $1.6(1.5-1.8)$ & $1.2(1.0-1.4)$ & $3.7(3.4-3.9)$ \\
\hline $95 \mathrm{y}$ & & & & \\
\hline Living alone & $0.2(0.2-0.3)^{*}$ & $1.2(1.1-1.4)^{*}$ & $1.0(0.8-1.2)$ & $2.4(2.2-2.7)^{*}$ \\
\hline Not living alone & $0.3(0.3-0.3)$ & $1.0(0.9-1.1)$ & $0.8(0.6-0.9)$ & $2.1(1.8-2.3)$ \\
\hline Female, age & & & & \\
\hline $65 \mathrm{y}$ & & & & \\
\hline Living alone & $3.7(3.4-4.1)^{* *}$ & $4.5(4.1-4.9)$ & $5.1(4.5-5.7)^{*}$ & $13.3(12.5-14.0)$ \\
\hline Not living alone & $4.8(4.3-5.3)$ & $4.1(3.8-4.5)$ & $4.0(3.6-4.5)$ & $12.9(12.1-13.8)$ \\
\hline $75 \mathrm{y}$ & & & & \\
\hline Living alone & $1.7(1.6-1.9)^{* *}$ & $3.3(3.1-3.5)$ & $3.9(3.5-4.3)^{*}$ & $8.9(8.5-9.4)$ \\
\hline Not living alone & $2.2(2.1-2.5)$ & $3.0(2.8-3.2)$ & $3.1(2.7-3.4)$ & $8.3(7.8-8.8)$ \\
\hline $85 \mathrm{y}$ & & & & \\
\hline Living alone & $0.7(0.7-0.8)^{* *}$ & $2.3(2.2-2.5)^{*}$ & $2.8(2.5-3.1)^{* *}$ & $5.8(5.5-6.2)^{*}$ \\
\hline Not living alone & $0.9(0.8-1.0)$ & $2.0(1.9-2.2)$ & $2.2(1.9-2.5)$ & $5.2(4.8-5.6)$ \\
\hline $95 \mathrm{y}$ & & & & \\
\hline Living alone & $0.3(0.2-0.3)^{*}$ & $1.6(1.4-1.7)^{*}$ & $1.9(1.6-2.2)^{*}$ & $3.7(3.4-4.1)^{*}$ \\
\hline Not living alone & $0.4(0.3-0.4)$ & $1.3(1.2-1.5)$ & $1.5(1.2-1.8)$ & $3.2(2.9-3.5)$ \\
\hline (C) Dementia medication & No formal care & Home care & Institutional care & Total duration \\
\hline Male, age & & & & \\
\hline $65 \mathrm{y}$ & & & & \\
\hline Dementia medication & $3.7(3.3-4.2)^{*}$ & $3.3(2.9-3.7)$ & $2.6(2.2-3.1)$ & $9.7(8.9-10.5)$ \\
\hline No dementia medication & $4.6(4.2-5.0)$ & $3.4(3.1-3.8)$ & $2.4(2.1-2.7)$ & $10.4(9.7-11.0)$ \\
\hline $75 \mathrm{y}$ & & & & \\
\hline Dementia medication & $1.7(1.5-1.9)^{*}$ & $2.4(2.1-2.6)$ & $1.9(1.6-2.3)$ & $6.0(5.5-6.5)$ \\
\hline No dementia medication & $2.1(1.9-2.3)$ & $2.4(2.3-2.6)$ & $1.7(1.6-2.0)$ & $6.3(5.9-6.7)$ \\
\hline 85 y & & & & \\
\hline Dementia medication & $0.7(0.6-0.8)^{*}$ & $1.6(1.4-1.8)$ & $1.3(1.1-1.6)$ & $3.6(3.3-4.0)$ \\
\hline No dementia medication & $0.8(0.8-0.9)$ & $1.6(1.5-1.8)$ & $1.2(1.0-1.4)$ & $3.7(3.4-3.9)$ \\
\hline $95 \mathrm{y}$ & & & & \\
\hline Dementia medication & $0.3(0.2-0.3)$ & $1.0(0.9-1.2)$ & $0.8(0.7-1.1)$ & $2.1(1.9-2.4)$ \\
\hline No dementia medication & $0.3(0.3-0.4)$ & $1.0(0.9-1.1)$ & $0.8(0.6-0.9)$ & $2.1(1.9-2.3)$ \\
\hline Female, age & & & & \\
\hline $65 \mathrm{y}$ & & & & \\
\hline Dementia medication & $3.9(3.3-4.4)^{*}$ & $3.9(3.5-4.5)$ & $4.3(3.6-5.0)$ & $12.1(11.0-13.2)$ \\
\hline No dementia medication & $4.8(4.3-5.3)$ & $4.1(3.8-4.5)$ & $4.0(3.5-4.6)$ & $12.9(12.1-13.8)$ \\
\hline & & & & ued on next page) \\
\hline
\end{tabular}


Supplementary Table 3 (continued)

\begin{tabular}{|c|c|c|c|c|}
\hline (C) Dementia medication & No formal care & Home care & Institutional care & Total duration \\
\hline \multicolumn{5}{|l|}{$75 \mathrm{y}$} \\
\hline Dementia medication & $1.8(1.6-2.1)^{*}$ & $2.8(2.5-3.2)$ & $3.3(2.8-3.9)$ & $7.9(7.3-8.7)$ \\
\hline No dementia medication & $2.2(2.0-2.5)$ & $3.0(2.8-3.2)$ & $3.1(2.7-3.5)$ & $8.3(7.8-8.9)$ \\
\hline \multicolumn{5}{|l|}{$85 \mathrm{y}$} \\
\hline Dementia medication & $0.8(0.6-0.9)^{*}$ & $2.0(1.7-2.2)$ & $2.4(2.0-2.8)$ & $5.1(4.5-5.6)$ \\
\hline No dementia medication & $0.9(0.8-1.1)$ & $2.0(1.9-2.2)$ & $2.2(1.9-2.5)$ & $5.2(4.8-5.6)$ \\
\hline \multicolumn{5}{|l|}{$95 \mathrm{y}$} \\
\hline Dementia medication & $0.3(0.2-0.3)$ & $1.3(1.1-1.5)$ & $1.6(1.3-2.0)$ & $3.2(2.8-3.7)$ \\
\hline No dementia medication & $0.4(0.3-0.4)$ & $1.3(1.2-1.5)$ & $1.5(1.2-1.8)$ & $3.2(2.9-3.5)$ \\
\hline
\end{tabular}

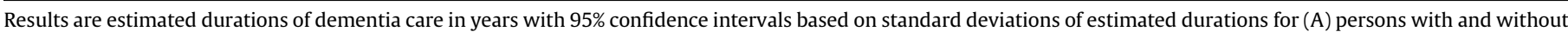

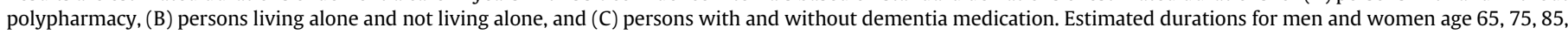

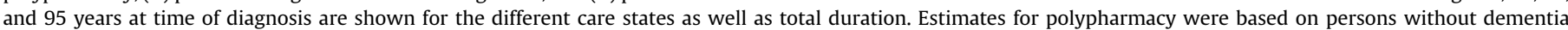

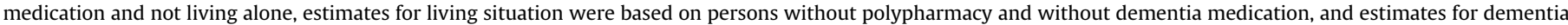
medication were based on persons without polypharmacy and not living alone.

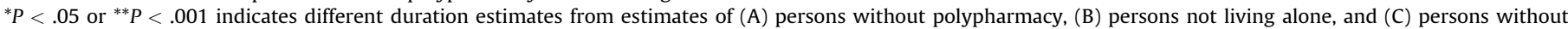
dementia medication. 
Supplementary Table 4

Estimated Dementia Care Durations in Years by (A) Migration Background and (B) Income, for Men and Women of Different Ages

\begin{tabular}{|c|c|c|c|c|}
\hline $\begin{array}{l}\text { (A) Migration } \\
\text { Background }\end{array}$ & No Formal Care & Home Care & Institutional Care & Total Duration \\
\hline \multicolumn{5}{|l|}{ Male, age } \\
\hline \multicolumn{5}{|l|}{$65 \mathrm{y}$} \\
\hline Western & $4.2(3.9-4.5)^{* *}$ & $3.6(3.4-3.9)$ & $2.2(2.0-2.5)^{*}$ & $10.0(9.6-10.5)^{*}$ \\
\hline Non-Western & $7.4(6.2-8.7)$ & $4.2(3.4-5.1)$ & $1.4(0.9-2.1)$ & $13.0(11.1-15.0)$ \\
\hline \multicolumn{5}{|l|}{$75 \mathrm{y}$} \\
\hline Western & $1.9(1.8-2.0)^{* *}$ & $2.6(2.4-2.7)$ & $1.6(1.5-1.8)$ & $6.1(5.8-6.3)^{*}$ \\
\hline Non-Western & $3.5(2.8-4.2)$ & $3.1(2.5-3.8)$ & $1.2(0.7-1.7)$ & $7.7(6.6-9.1)$ \\
\hline \multicolumn{5}{|l|}{$85 \mathrm{y}$} \\
\hline Western & $0.7(0.7-0.8)^{* *}$ & $1.7(1.6-1.8)$ & $1.1(1.0-1.2)$ & $3.5(3.4-3.7)$ \\
\hline Non-Western & $1.3(1.1-1.7)$ & $2.1(1.6-2.6)$ & $0.9(0.5-1.4)$ & $4.3(3.5-5.3)$ \\
\hline \multicolumn{5}{|l|}{$95 \mathrm{y}$} \\
\hline Western & $0.2(0.2-0.3)^{*}$ & $1.0(0.9-1.1)$ & $0.7(0.6-0.8)$ & $2.0(1.8-2.2)$ \\
\hline Non-Western & $0.4(0.3-0.6)$ & $1.3(0.9-1.7)$ & $0.6(0.3-1.0)$ & $2.3(1.8-3.0)$ \\
\hline \multicolumn{5}{|l|}{ Female, age } \\
\hline \multicolumn{5}{|l|}{$65 \mathrm{y}$} \\
\hline Western & $4.2(3.9-4.5)^{* *}$ & $4.7(4.4-5.0)$ & $4.1(3.8-4.5)^{*}$ & $13.0(12.4-13.6)^{*}$ \\
\hline Non-Western & $7.6(6.5-8.8)$ & $5.7(4.6-7.0)$ & $2.6(1.7-3.9)$ & $15.9(14.1-18.1)$ \\
\hline \multicolumn{5}{|l|}{$75 \mathrm{y}$} \\
\hline Western & $1.9(1.8-2.0)^{* *}$ & $3.4(3.2-3.5)$ & $3.2(3.0-3.4)$ & $8.5(8.2-8.8)$ \\
\hline Non-Western & $3.7(3.0-4.5)$ & $4.3(3.4-5.1)$ & $2.2(1.4-3.3)$ & $10.1(8.5-12.0)$ \\
\hline \multicolumn{5}{|l|}{$85 \mathrm{y}$} \\
\hline Western & $0.8(0.7-0.8)^{* *}$ & $2.3(2.2-2.4)$ & $2.3(2.2-2.5)$ & $5.4(5.2-5.6)$ \\
\hline Non-Western & $1.5(1.2-1.9)$ & $3.0(2.4-3.7)$ & $1.7(1.1-2.6)$ & $6.2(5.1-7.6)$ \\
\hline \multicolumn{5}{|l|}{$95 \mathrm{y}$} \\
\hline Western & $0.3(0.2-0.3)^{* *}$ & $1.5(1.4-1.6)$ & $1.6(1.4-1.8)$ & $3.4(3.2-3.6)$ \\
\hline Non-Western & $0.5(0.4-0.7)$ & $2.0(1.5-2.5)$ & $1.2(0.8-1.8)$ & $3.8(3.0-4.7)$ \\
\hline (B) Income & No formal care & Home care & Institutional care & Total duration \\
\hline \multicolumn{5}{|l|}{ Male, age } \\
\hline \multicolumn{5}{|l|}{$65 \mathrm{y}$} \\
\hline Higher income & $4.9(4.5-5.3)^{* *}$ & $3.7(3.5-4.0)$ & $2.1(1.9-2.3)$ & $10.7(10.2-11.3)^{*}$ \\
\hline Lower income & $3.8(3.5-4.1)$ & $3.6(3.3-3.8)$ & $2.3(2.0-2.5)$ & $9.6(9.1-10.1)$ \\
\hline \multicolumn{5}{|l|}{$75 \mathrm{y}$} \\
\hline Higher income & $2.2(2.0-2.3)^{* *}$ & $2.6(2.5-2.8)$ & $1.6(1.4-1.7)$ & $6.4(6.1-6.6)^{*}$ \\
\hline Lower income & $1.7(1.5-1.8)$ & $2.5(2.4-2.7)$ & $1.7(1.5-1.8)$ & $5.9(5.6-6.1)$ \\
\hline \multicolumn{5}{|l|}{$85 \mathrm{y}$} \\
\hline Higher income & $0.8(0.8-0.9)^{* *}$ & $1.7(1.6-1.8)$ & $1.1(1.0-1.2)$ & $3.6(3.4-3.8)$ \\
\hline Lower income & $0.6(0.6-0.7)$ & $1.7(1.6-1.8)$ & $1.2(1.0-1.3)$ & $3.5(3.3-3.6)$ \\
\hline \multicolumn{5}{|l|}{$95 \mathrm{y}$} \\
\hline Higher income & $0.3(0.2-0.3)^{*}$ & $1.0(0.9 .1 .1)$ & $0.7(0.6-0.8)$ & $2.0(1.8-2.2)$ \\
\hline Lower income & $0.2(0.2-0.2)$ & $1.0(0.9-1.1)$ & $0.7(0.6-0.9)$ & $2.0(1.8-2.2)$ \\
\hline \multicolumn{5}{|l|}{ Female, age } \\
\hline \multicolumn{5}{|l|}{$65 \mathrm{y}$} \\
\hline Higher income & $5.0(4.7-5.4)^{* *}$ & $4.9(4.6-5.3)$ & $3.9(3.5-4.3)$ & $13.8(13.1-14.5)^{*}$ \\
\hline Lower income & $3.8(3.5-4.2)$ & $4.5(4.2-4.9)$ & $4.2(3.8-4.6)$ & $12.6(12.0-13.2)$ \\
\hline \multicolumn{5}{|l|}{$75 \mathrm{y}$} \\
\hline Higher income & $2.3(2.2-2.5)^{* *}$ & $3.5(3.3-3.7)$ & $3.1(2.8-3.4)$ & $8.9(8.5-9.3)^{*}$ \\
\hline Lower income & $1.7(1.6-1.8)$ & $3.3(3.1-3.4)$ & $3.3(3.0-3.5)$ & $8.2(7.9-8.5)$ \\
\hline \multicolumn{5}{|l|}{$85 \mathrm{y}$} \\
\hline Higher income & $0.9(0.8-1.0)^{* * *}$ & $2.4(2.2-2.5)$ & $2.3(2.1-2.5)$ & $5.6(5.3-5.9)$ \\
\hline Lower income & $0.7(0.6-0.7)$ & $2.3(2.2-2.4)$ & $2.4(2.2-2.6)$ & $5.3(5.1-5.5)$ \\
\hline \multicolumn{5}{|l|}{$95 \mathrm{y}$} \\
\hline Living alone & $0.3(0.2-0.3)^{*}$ & $1.6(1.4-1.7)^{*}$ & $1.9(1.6-2.2)^{*}$ & $3.7(3.4-4.1)^{*}$ \\
\hline Not living alone & $0.4(0.3-0.4)$ & $1.3(1.2-1.5)$ & $1.5(1.2-1.8)$ & $3.2(2.9-3.5)$ \\
\hline
\end{tabular}

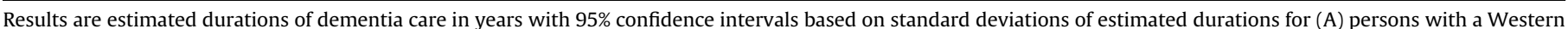

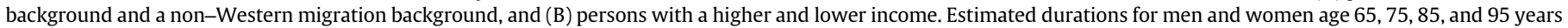
at time of diagnosis are shown for the different care states as well as total duration.

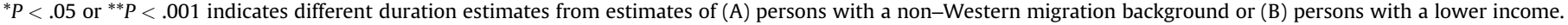

